\title{
Assessment of the Fire Effect on Water Balance Components Under Different Land Uses, Central Zagros, Iran Case Study
}

Khodayar Abdollahi ( $\sim$ kabdolla2010@gmail.com )

Shahrekord University https://orcid.org/0000-0001-7274-0823

AliAsghar Naghipour

Shahrekord University

Samira Bayati

Shahrekord University

Zahra Eslami

Shahrekord University

Forrest W Black

Mississippi State University

\section{Research Article}

Keywords: Biomass burning, Water budget, water cycle dynamics, WetSpass-M model

Posted Date: July 16th, 2021

DOl: https://doi.org/10.21203/rs.3.rs-268307/v1

License: (9) This work is licensed under a Creative Commons Attribution 4.0 International License. Read Full License 


\section{Assessment of the fire effect on water balance components under different land uses, Central Zagros, Iran case study}

Khodyar Abdollahi ${ }^{* 1}$, AliAsgharNaghipour ${ }^{2}$, Samira Bayati $^{2}$, ZahraEslami $^{2}$, Forrest W Black ${ }^{3}$

3

\section{$4 \quad$ Abstract} coefficient.

Background: Fire occurrence may lead to a significant impactin many terrestrial ecosystems. This study attempted to evaluate the effects of fire on the water balance components in the Central Zagros, Iran. The study used two modeling frameworks, including WetSpass-M and Bayesian Belief Networks to investigate the effect of fire on the amount of runoff, groundwater recharge and evapotranspiration. The first part of the study was a water balance simulation at a monthly scale. In addition, a Bayesian belief networks was applied to explore and understand key issues affect in the water balance after fire. Calibration and validation of the WetSpass-M model was performed without considering the effect of fire (2000-2014) and then the model was run again to with the fire scenario by reducing manning roughness coefficient and increasing the $\theta$

Results: Calibration and validation were performed before finalizing the simulation. A NashSutcliff coefficient of 0.61 and 0.58 was obtained during the calibration and validation respectively. The analysis of the water balance components results depicted that fire has increased the amount of runoff and it has reduced the amount of groundwater recharge and actual evaporation especially in the sparse forest and poor, medium and good rangelands.

Conclusions: Water balance components of each class, i.e. sparse forest, poor, medium and good rangelands were different under fire/non-fire scenarios. The percentage of change in the water balance components were used for comparison. The results of Bayesian model for post-fire 
scenario showed a significant increase in runoff due to reduced vegetation in the area. Both

24 simulated groundwater recharge and surface flow have showed a reduction rate in the fire

25 occurrence scenario. A similar conclusion was obtained from probabilistic Bayesian model due

26 to reducing vegetation cover and surface changes. Actual evapotranspiration component for the

27 poor rangeland has dropped off significantly. Therefore, there is a need for monitoring

28 hydrologic dynamics of the lands with a high risk of burning.

29 Keywords: Biomass burning, Water budget, water cycle dynamics, WetSpass-M model.

1.* Department of Nature Engineering, Shahrekord University, Shahrekord, Iran; kabdolla@sku.ac.ir

2. Shahrekord University, Shahrekord, Chaharmahal, Department of Natural Engineering 3.Department of Geosciences, University of Missouri - Kansas City, 5100 Rockhill Road, KansasCity, MO 64110; 816217 1929;

\section{Introduction}

32 Fire is a major negative factor for the most natural ecosystems along with urban excessive development of agricultural lands (Yin et al., 2005). It is also one of the most important physical

34 factors that affect many environmental processes (Thomazet et al., 2014). These impacts mostly lead to changes in land cover and soil characteristics (Shakesby, 2011).In the case of wild fires,

they not only reduce the land cover of the natural ecosystems, but also result in damages soil

37 damaged soil due leads to an increased rain droplet exposure. Therefore, it has an important effect on hydrological conditions that are vital to soil loss by increasing hydrophobicity of the soil. There are some reports where burring of land surface reduces permeability (Hemmatboland et al., 2010). This influences soil water balance as it can reduce the amount of infiltrated water

41 (Madsen et al., 2012), increase the surface flow, intensify the surface flow rate and has a high 42 impact on partitioning of water compared to pre-firing conditions (De Bano, 2000; Benavides- 
43 Solario and MacDonald, 2001\&2005; Kunze and Stednick, 2006; Shakesby and Doerr, 2006;

44 Moody et al,. 2009). The degree of change in water balance components depend on the surface

45 response and intensity of soil disorder (Heydari et al., 2012).Even stability of soil structure may

46 be reduced due to slights (Mataix-Solera and Doerr, 2004) while the stability of soil structure

47 after severe fires may be more likely to lead to increasing bulk density and blockage of soil pores

48 (Martin and Moody, 2001; Badia and Marti, 2003). Certain changes in soil chemical

49 characteristics and soil regime is expected after severe wildfire (Kavdir et al., 2005).For many

50 natural ecosystems, wild fire may lead to the change in structure and function of the ecosystems

51 (Bond and Keeley, 2005; Bahlakeh et al., 2017). Wild fires are mostly due to human activities,

52 however they may also occur naturally. For instance, they might occur due to lightning (Leone et

53 al. 2009; Papakosta and Straub 2011). Wildfires also considered as a key environmental concern

54 for plant ecosystems (Renard et al., 2012), where as they annually destroy million hectares of 55 ecosystems(FAO, 2010). Iran is ranked fourth in terms of forest fires in the Middle East and 56 North Africa (Adab et al., 2011). For citing an example case according to the Iran Statistic

57 Center report, during the period between 2014and 2018, as many as9962cases of firehavebeen 58 recorded in Iran, which caused the burning of approximately78000 hectares of natural 59 resources(National Agricultural Statistics, 2014-2018).In terms of future perspectives, due to 60 climate change and human activates on land use, it is expected that this trend will continue and/or 61 will even increase in the future (Eskandari and Chuvieco, 2015). However, the risk of fire is not 62 the same during the wet and dry periods. The results of Black et al. (2016) showed that fires 63 increase during the dry season and decrease in the wet season. Increased wildfires can lead to 64 strict decrease in hydrological processes. 
65 Fire has a significant effect on water budget. The study conducted by Flerchinger and Clark

66 (2003) indicate the first year after the fire had less evaporation, more permeability in some

67 areas, and runoff isleft without significant changes as opposed to non-fires. Gonzalez-Pelayo et

68 al. (2010) examined hydrological processes such as runoff and penetration from July 2002 to

69 July 2004 on a plot scale in Spain. Their study showed that in the post-fire period, runoff was

70 increased by $20 \%$ and water penetration to soil was reduced by $18 \%$.

71 Gholami-Gohareh et al.(2012) have discussed the forest fire in the Mazandaran province of Iran

72 caused aninc rescent of 118 and 152 percent in both runoff and sedimentation, while they have

73 reported while this has resulted in a 101.4 percent reduction of 18 percent in.

74 Results byHeydari et al. (2014) in the semi-steppe pastures of the KarsanakBasin in the

75 Chaharmahal-Bakhtiari province in the western parts of Iran, demonstrated that fire caused a

76 decrease of the soil organic in surface samples for the first and second years after the fire and

77 reduced the mineralization of soil carbon in the surface layer, one year after the fire. They also

78 stated the negative effects of fire land cover on soil properties in the first year after the fire were

79 more considerable than the second or third years.

80 The aim of the current studyis to investigate the relationship between fire andsimulated water

81 balance components using the WetSpass-M in the Karebas Basin, a high land located in the

82 Central Zagros geographically. The applied model is a kind of distributed model that calculates

83 the overall water balance for each cell from the independent sub-pixel water budget for each land

84 cover including bare soil, water reservoirs and impermeable land. This means the model takes

85 advantage of a hetero gonousland use for each cell instead of assuming a uniform area for each

86 pixel (Batelaan and De Smedt, 2001). WetSpass-M was wildly used for the change assessment in

87 studies related to investigation of theimpactsof land use changeson the groundwater systems, 
88 simulation of water balance components (Paul, 2006;Pan et al., 2011), investigation of the

89 climate change effects on water resources (Woldeamlak et al.,2007; Wang et al., 2015; Shrestha

90 et al., 2016; Kajewska-Szkudlarek et al., 2017), assessment of the impacts of urbanization on

91 water balance (Zhang et al., 2017; Graf and Jawgiel, 2018), and studies related to the interaction

92 between ground water and water balance components (Al Kuisi and El-Naqa, 2013;

93 Gebreyohannes et al. 2013; Graf and Przybylek, 2014; Pandian et al., 2014; Zarei et al.,

94 2016;Soleimani-Motlagh, 2017).

95 The occurrence of the fire phenomenon is a frequent event in the central Zagros region of Iran.

96 Similar to other parts of the world, this destructive phenomenon has caused severe after effects to

97 the environment and land cover of natural ecosystems in the region (Naghipour et al., 2016).In

98 the central Zagros region, especially within the Karebas region, the occurrence of fires in these

99 habitats becomes more frequent during drought periods with the reduction in rainfall. This study

100 attempts to investigate the cause and its impact of biomass burring on water balance components

101 in thearea of interest.

102 2. Materials and Methods

$103 \quad$ 2.1. Study area

104 The Karebas Basin is located between $55^{\circ} 26^{\prime}-56^{\circ} 04^{\prime}$ E longitude and $37^{\circ} 25^{\prime}-37^{\circ} 47^{\prime}$

105 Nlatitudewith2,825 $\mathrm{km}^{2}$ area. This transboundary area is geographically situated between

106 Chaharmahal-Bakhtiari and Esfahan provinces in the western part of Iran (Fig. 1). The basin is a

107 mountainous region located in the center of the Zagros mountains with an elevation range

108 of $1,760 \mathrm{~m}$ to $3,794 \mathrm{~m}$. The area west of the basin is mostly mountainous with high altitude and

109 the eastern parts consist of low-slopes and flat areas. The land cover of this study consist of poor 
rangeland, moderate rangeland, and good rangeland with sparse forests that cover 25, 20, 4, and

11126 percent of the basin area, respectively. According to the information released by of the Forest,

112 Rangeland and Watershed Organization of the Iran, the canopy density in sparse forests and poor

113 rangeland is 5 to 25 percent while the canopy density in the moderate rangeland varies in rang of

11425 to 50 percent. For the good rangeland, this value is more than 50 percent.

115 Our field investigation indicates that for most fire cases, the cause is due to human factors.

116 Previous reports also noted that the impact of human factors could possibly be related to the

117 economic and social problems of the central Zagros region. There are several researches

118 highlighting strong dependence of the resident people on the natural resources (Bashariet $119 a l ., 2016)$.

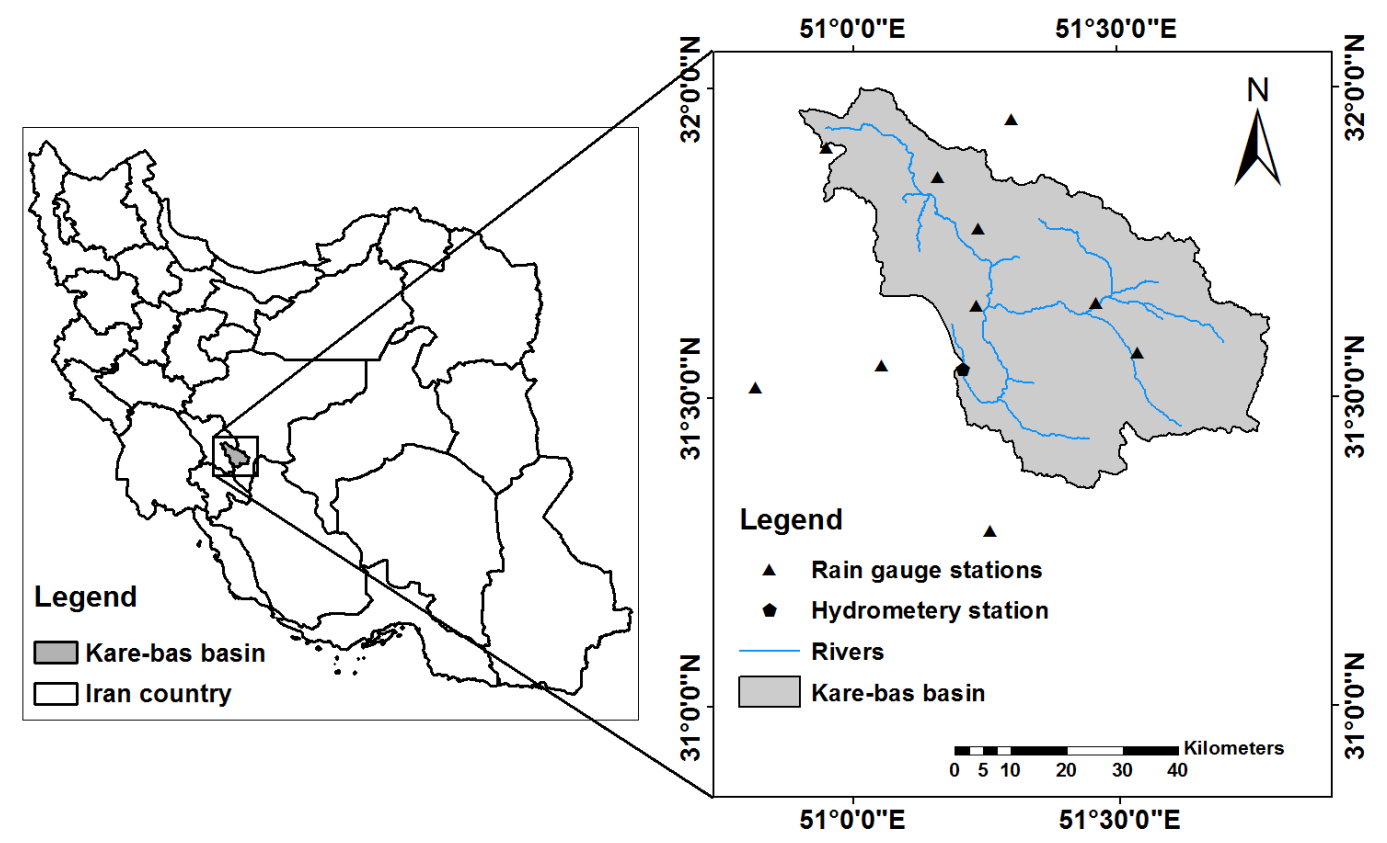

Fig. 1.The location map of the Karebas basin in Iran. 
124 The WetSpass ${ }^{1}$ model was developed by the Hydrological and Hydraulic Institute of the 125 University of Brussels to predict the transfer of water and energy between soil, plant, and 126 atmosphere in a quasi-steady state. The first version of this model was based on time and 127 dependent on the spatial distribution model of the WetSpa water balance (Wang et al., 1997) 128 which is used to predict hydrological processes in a distributed methodology. The original model 129 was scripted in ArcView software and based on annual and seasonal time scales (Al Kuisiand El130 Naqa, 2013). A newer model version was developed by Abdollahi et al. (2012) named 131 WetSpass-M with the ability of simulating interception, runoff, evapotranspiration, soil water 132 balance, and groundwater recharge at a monthly time scale.The recent version of the model is 133 independent of the ArcView software. While the original model was designed for temperate 134 regions, WetSpass-M has been developed to simulate water balance in arid and semi-arid 135 regions. The model is capable of simulating the long-term temporal and spatial variations of 136 water balance components, including runoff, actual evapotranspiration, and groundwater 137 recharge (Wang et al., 2015).One of the capabilities of this model is to study the effect of land 138 use and climate change on groundwater recharge systems, investigating the effect of climate 139 change on the spatial and temporal patterns of water resources by estimating the components of 140 water balance. In this methodology, the overall water balance for a grid cell is calculated from 141 water budget for vegetated area, bare soil, open water/reservoirs, and impervious surface of each 142 cell(Batelaan and De Smedt, 2001):

$$
\begin{aligned}
& E T_{\text {raster }}=a_{v} E T_{v}+a_{s} E T_{s}+a_{O} E T_{O}+a_{i} E T_{i} \quad \text { Eq. } 1 \\
& S_{\text {raster }}=a_{v} S_{v}+a_{s} S_{s}+a_{O} S_{O}+a_{i} S_{i} \quad \text { Eq. } 2 \\
& \begin{array}{ll}
R_{\text {raster }}=a_{v} R_{v}+a_{s} R+a_{O} R_{O}+a_{i} R_{i} & \text { Eq. } 3
\end{array}
\end{aligned}
$$

\footnotetext{
${ }^{1}$ Water and Energy Transfer between Soil, Plants and Atmosphere under quasi-steady state
} 
144 Where $\mathrm{ET}_{\text {raster, }} \mathrm{S}_{\text {rasterand }} \mathrm{R}_{\text {raster }}$ values are evapotranspiration, surface runoff, and groundwater

145 recharge respectively (all units expressed in millimeters), $a_{v}, a_{s}, a_{o}$ and $a_{i}$ are related to areas of 146 vegetated cover, bare soil, open water/reservoirs and impervious surface of the grid the cell 147 respectively. The water balance in this model is defined as:

$P=I+S_{v}+T_{v}+R_{v}$

149 Where $\mathrm{P}, \mathrm{I}, \mathrm{S}_{\mathrm{v}}, \mathrm{T}_{\mathrm{v}}$, and $\mathrm{R}_{\mathrm{v}}$ are precipitation, interception, surface runoff, evapotranspiration and 150 groundwater recharge respectively (all in millimeters) (Abdollahi et al., 2017). The amount of 151 runoff in this model is calculated via Equation 5:

$$
\begin{array}{lr}
S R_{m}=C_{S r} C_{h}\left(P_{m}-I_{m}\right) & \text { Eq. } 5 \\
C_{h}=P_{m} / L P\left(P_{m}^{\alpha}+E T_{m}^{\alpha}\right)^{1 / \alpha} & \text { Eq. } 6 \\
C_{s r}=C_{w p} \bar{P}_{24} / C_{w p} \bar{P}_{24}-R C D \times C_{w p}+R C D & \text { Eq. } 7 \\
C_{w p}=\left(1-A_{\text {Imp }} / 100\right) C_{p e r}+\left(A_{\text {Imp }} / 100\right) C_{\text {Imp }} & \text { Eq. } 8 \\
C_{p e r}=W 1(0.02 / n)+W 2\left(\theta_{w} /\left(1-\theta_{w}\right)\right)+W 3\left(S_{p} /\left(10+S_{p}\right)\right) & \text { Eq. } 9 \\
C_{\text {Imp }}=0.9 e^{0.024 A_{\text {Imp }}} & \text { Eq. } 10
\end{array}
$$

153 Where $\mathrm{SR}_{\mathrm{m}}, \mathrm{P}_{\mathrm{m}}$, and $\mathrm{I}_{\mathrm{m}}$ are the amount of surface runoff, precipitation and monthly interception 154 respectively (all in millimeters). $\mathrm{C}_{\mathrm{h}}$ is a descriptive coefficient of soil moisture content 155 (dimensionless) that is calculated from equation 6; when the potential evapotranspiration is 156 greater than the monthly precipitation, otherwise the value of $C_{h}$ is equal to 1. 
$157 \mathrm{ET}_{\mathrm{m}}, \mathrm{LP}$, as well as $\alpha$ are potential evapotranspiration (in $\mathrm{mm} / \mathrm{month}$ ), the dimensionless 158 calibration coefficient of effect of evapotranspiration on surface runoff and evapotranspiration 159 coefficient respectively.

$160 \mathrm{C}_{\mathrm{sr}}, \mathrm{C}_{\mathrm{wp}}, \mathrm{RCD}, \mathrm{A}_{\mathrm{Imp}}, \mathrm{C}_{\mathrm{per}}, \mathrm{C}_{\mathrm{Imp}}, \mathrm{n}$, and $\mathrm{S}_{\mathrm{p}}$ are also the actual runoff coefficient (dimensionless), 161 potential runoff coefficient, average daily precipitation (millimeter per day in month),level 162 ofregional consecutive dryness (in millimeters), permeable area, runoff coefficient of permeable 163 areas, runoff coefficient of impermeable areas, Manning roughness coefficient, volumetric 164 moisture content of soil at the wilting point, and the gradient of the land's surface in percent, 165 respectively. $\mathrm{W}_{1}, \mathrm{~W}_{2}$ and $\mathrm{W}_{3}$ represent three constituent weights for $\mathrm{C}_{\mathrm{per}}$, namely the slope factor, 166 land use factor, and soil texture factor (Abdollahi, 2015). In order to give more importance to the 167 land surface characteristics in the fire processes, the values of $0.2,0.4$ and 0.4 coefficients, were 168 selected for these weights, respectively.

169 Groundwater recharge, $\mathrm{R}_{\mathrm{m}}$ was obtained as the residual of the water balance in WetSpass-M(Eq. 170 11). Monthly base-flow for each cell based on the previous month's storage and groundwater 171 recharge in the current month are calculated via equation 12 (Abdollahi et al., 2017):

$R_{m}=P_{m}-S R_{m}-E T_{m}$ Eq. 11

$Q_{b(t)}=\beta Q_{b(t-1)}+0.001 N_{m}(1-\beta) \emptyset R_{m}$

Eq. 12

173 Where $\beta$ is the storage parameter (between zero and one), $\mathrm{Q}_{\mathrm{b}(\mathrm{t}-1)}$ is the previous month's base174 flow (in cubic meter per month), $\mathrm{N}_{\mathrm{m}}$ the number of days per month and $\emptyset$ the contributing 175 parameter in recharge for the current base-flow in square meters per day (Arnold And Allen, 176 1999). 


\subsection{Water balance model data requirements}

179 The input data requirements for the water balance model include soil texture maps, land use, 180 slope, elevation digital model, evaporation from the pan, precipitation, number of rainy days, 181 groundwater depth, temperature, wind speed at a height of two meters, and the depth of 182 groundwater. Thedata in this research were collected from the Ministry of Energy, the Natural 183 Resources and Watershed Management office and the regional water company of Chaharmahal184 Bakhtiari province, the Regional Water Organization of Isfahan, and the Meteorological 185 Organization of Iran. Then monthly maps were rasterized using the Kriging interpolation 186 method. The number of rainy days and degree day were also calculated as a spatial average. The

187 time series of leaf area index and snow maps are also were used in the modeling. The snow cover 188 maps were collected using the temperature index method and the leaf area index collected from 189 the MODIS website an ascii raster maps.

190 The volumetric values of surface water discharge were used to compare simulated results with its 191 observational values. The gauge station discharge values were separated into surfaceand base192 flow (Willems, 2009) using a recursive digital filter method (WHAT software) which the 193 equation of this method is presented in the following equation (Eckhardt, 2008).

$q_{t}=\left(1-B F I_{\max }\right) \alpha \times q_{t-1}+(1-\alpha) B F I_{\max } Q_{t} / 1-\alpha B F I_{\max } \quad$ Eq. 13

195 Where qtis the filtered base-flow at time $\mathrm{t}, \mathrm{q}_{\mathrm{t}-\mathrm{l}}$ is the filtered base-flow at time $\mathrm{t}-1$ and $\mathrm{Q}_{\mathrm{t}}$ is the 196 total flow at time $\mathrm{t}$ (all in $\mathrm{m}^{3} / \mathrm{s}$ ), $\alpha$ the constant recession curve and $\mathrm{BFI}_{\max }$ is the maximum value 197 of the base-flow index. The filter considers both the hydrological characteristics of the flow and 
198 the basin (Eckhardt, 2008). The method requires the determination of two parameters; the fixed 199 recession curve for the catchment area and the maximum value of the base-flow index. In this 200 study, $\alpha$ and $\mathrm{BFI}_{\max }$ are 0.75 and 0.36 respectively.
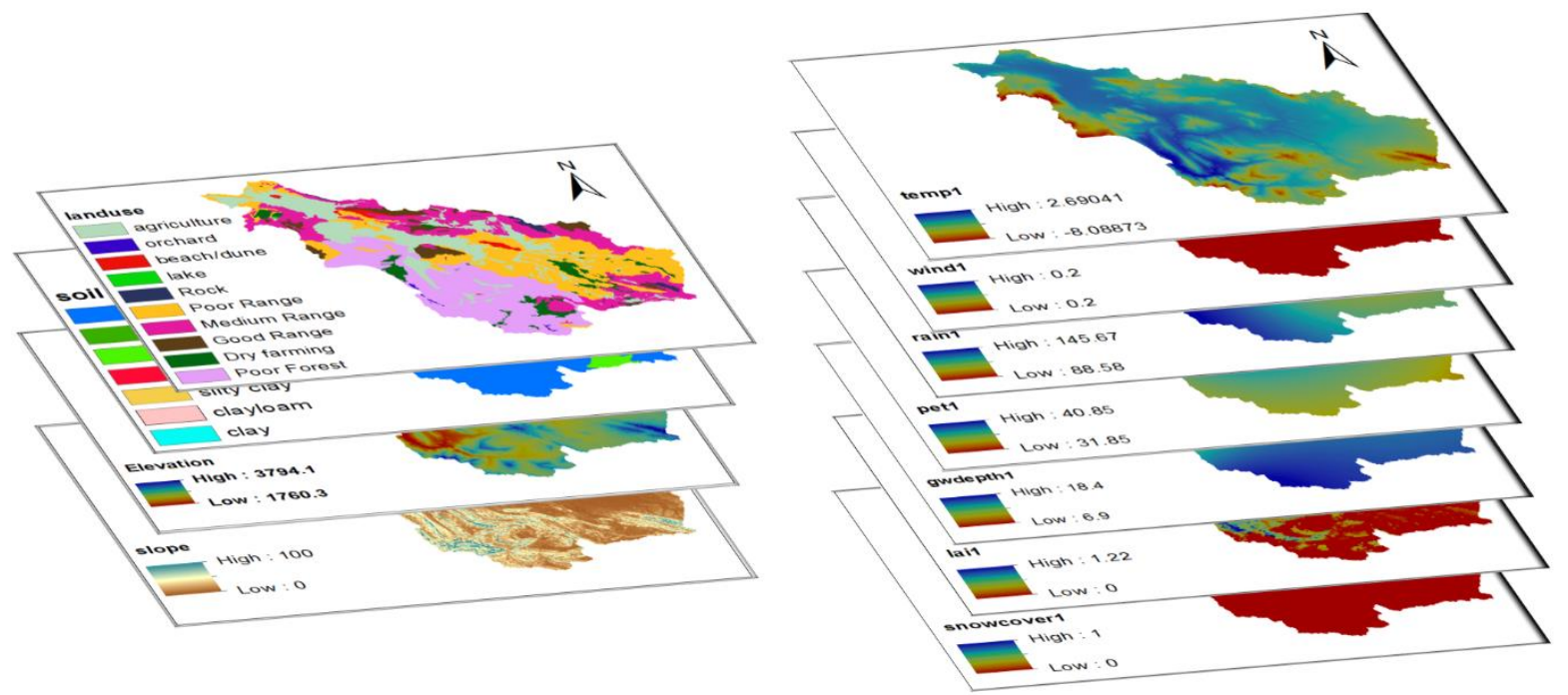

Fig. 2.A schematic view of the input maps.

\subsection{Field sampling}

In different parts of the region, both intentional and non-intentional fires have occurred throughout the past several years. Since variation of the land cover are affected by fire sites in

207 each study, land use including good, medium and poor rangelands, as well as forest (total 12

208 sites) were visited for one-year fire. The term one-year fire refers to a location that fire has

209 occurred over one year before the sampling. For each fire occurrence area, appear no fire area

210 (control) was identified adjacent to the sampling area. Figures 3 and 4, show images of different

211 land cover in the control and fire areas respectively. The stratified random sampling method was

212 used after preliminary identification and determination of study sites. In each sampling site, 20 
213 plots of 4 square meters were installed which 10 plots in the fire area and 10 plots in the control 214 area. The canopy cover percentage of each plant species was recorded.
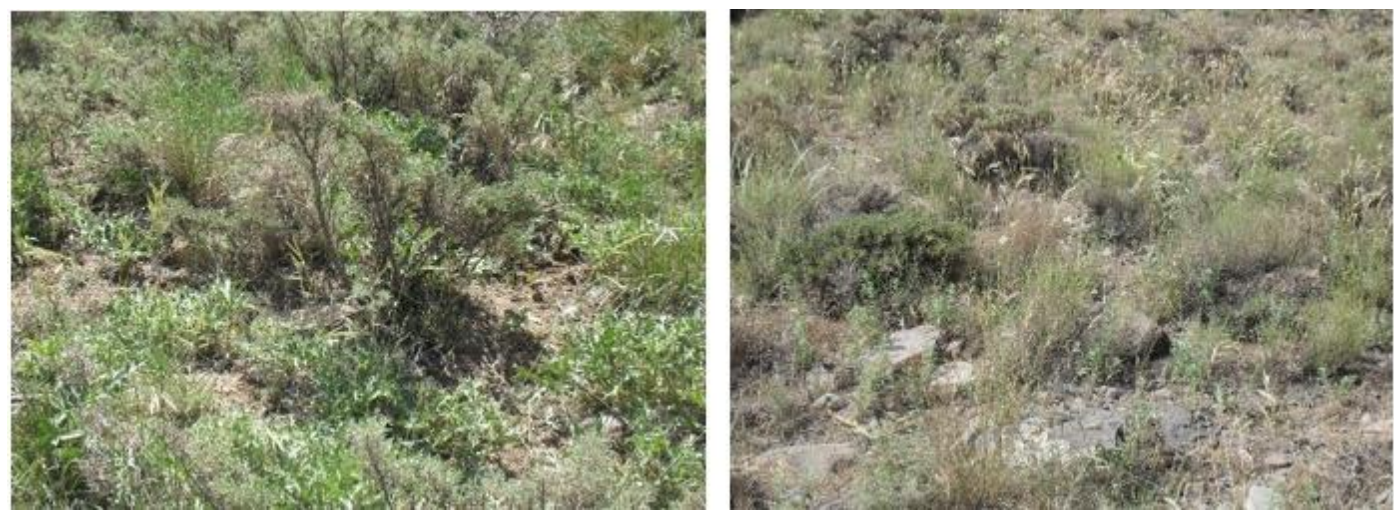

Fig. 3. An example of the land cover in the control area.
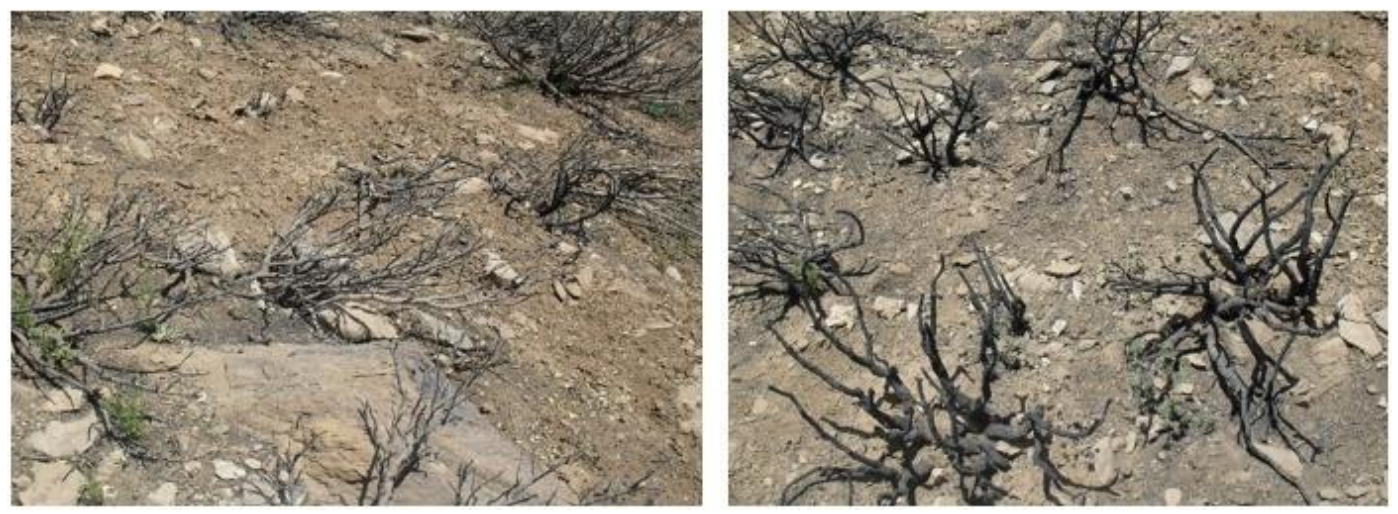

Fig. 4. An example of theland cover in the fire area.

\subsection{Modeling Method}

222 As previously explained, WetSpass-M methodology was adopted to simulate monthly water

223 balance. The period of calibration and validation was for2004-2014 and 2000-2003, respectively.

224 After parameterization of the water balance model, two scenarios were used to perform modeling 
225 the water balance. The first scenario was the modeling of water balance under non-fire

226 conditions, which the model applied using the prepared maps with no consideration of fire and

227 the second scenario was related to water balance modeling considering the occurrence of fire.

228 Since fire has a significant impact on land surface features, two time series of LAI monthly maps

229 were used, in order to consider the effect of fire on land cover on the base field collected fire/no

230 fire data. The land cover percentage was adopted based on the control and fire areas and

231 decreasing coefficients were used to capture leaf area index values for land cover after the fire in

232 the sparse forests, poor, medium and good rangelands. Literature review of Stoof et al. (2015)

233 showed that the fire reduced the Manning soil roughness coefficient. Manning's roughness

234 decreased by $56 \%$ in this study, which was applied for modeling water balance in the second

235 scenario. A similar procedure was used for the soil parameter of $\theta$, where the land cover was

236 sparse forests, poor, medium, and good rangelands. Lastly, the simulated values for water

237 balance components in both scenarios were compared.

\subsection{Evaluation of water balance model efficiency}

239 The model outputs included runoff maps, actual evapotranspiration and groundwater recharge,

240 along with average values of these outputs. In this study, the performance of the model was

241 evaluated by using the Nash-Sutcliffe efficiency coefficient (Nash and Sutcliffe, 1970) which

242 was calculated as follows:

$E N S=1-\Sigma\left(Q_{o b s}-Q_{s i m}\right)^{2} / \Sigma\left(Q_{o b s}-\overline{Q_{o b s}}\right)^{2}$

Eq. 14

244 Where $\mathrm{Q}_{\text {obs }}$ is the observed flow, $\mathrm{Q}_{\text {simis }}$ the estimated flow, $\overline{\mathrm{Q}_{\mathrm{OBS}}}$ is the average of the observed 245 flow, and $\overline{\mathrm{Q}_{\text {sim }}}$ is the average of the estimatedflow. 


\subsection{Bayesian belief networks modeling}

247 In order to assess the fire effect on water balance components, a Bayesian Belief Networks

248 (BBN) methodology was applied. Bayes' rule provides an underpinning for the inferential 249 mechanisms for prediction and diagnosis describing both positive and negative impacts of fire on 250 the water balance components using BBNs.Netica software version 5.15 (Norsys Software 251 Corporation 2014)was used for this purpose. BBNs are mathematical and visual models that 252 provide a better understanding of cause-and-effect relationships among the contributing 253 variables.In a $\mathrm{BBN}$, each variable is represented by a node, in order that the number of nodes 254 indicates the number of variables involved in the modeling. Each node contains a discrete set of 255 statesand the information about the meaningful relationships as a set of conditional probability. 256 For each node, a set of states may be specified. The graphical representation of BBN contains a 257 number of variables/nodes and their directed edges/causal relationships. If no edge exists 258 between two nodes, then this implies the state is conditionally independent. After factorizing the 259 joint probability distribution for interconnected variables, a directed acyclic graph (DAG) was 260 established. By structuring the available information and expert opinion a network diagram was 261 created.

262 Mutual information analysis method was used to rank the degree of individual and conjoint 263 influence of each input on output. Mutual information is a measure that determines to what 264 extent one variable can express to the other one. In Bayesian models, this is a useful indicator to 265 find the variables that strongly affect the behavior of the system or the variables where the 266 system is not very sensitive to their change. Through sensitivity analysis of developed BBN, the 267 most critical factors in the soil water balance were determined. Using this framework, the state of 268 water balance components considering with/without the effect of fire on vegetation and soil was 
269 investigated. Table 1 shows the sources information and independent variables used in the

270 model. The containing variables in this table are based on the variables used in WetSpass-M.

Table 1.Description of independent variables and their sources used in the BBN model

\begin{tabular}{|c|c|c|}
\hline Variable & Type & States (classes) \\
\hline Water Balance in Soil & Discrete & Very Dry, Dry, Normal, Wet, Very Wet \\
\hline Mean Annual & Continuous & Low $\left(<12^{\circ} \mathrm{C}\right)$, Medium $\left(12-16^{\circ} \mathrm{C}\right)$, High $\left(>16^{\circ} \mathrm{C}\right)$ \\
\hline \multicolumn{3}{|l|}{ Temperature } \\
\hline Potential evaporation & Continuous & $\begin{array}{l}\text { Low }(<1500 \mathrm{~mm}) \text {, Medium }(1500-3000 \mathrm{~mm}) \text {, High }(>3000 \\
\mathrm{mm})\end{array}$ \\
\hline Mean Annual & Continuous & Low $(<250 \mathrm{~mm})$, Medium $(250-500 \mathrm{~mm})$, High $(>500 \mathrm{~mm})$ \\
\hline \multicolumn{3}{|l|}{ Precipitation } \\
\hline Wind Speed & Continuous & Low (<6 nut), Medium (6-16 nut), High ( $>16$ nut) \\
\hline Slope & Continuous & Gentle $\left(<5^{\circ}\right)$, Moderate $\left(5-15^{\circ}\right)$, Steep $\left(>15^{\circ}\right)$ \\
\hline Percentage of vegetation & Continuous & Low (<25\%), Medium (25-50\%), High $(>50 \%)$ \\
\hline Elevation & Continuous & Low (<1000 m), Medium (1000-2000 m), High (>2000 m) \\
\hline Manning coefficient & Continuous & Low $(<0.05)$, Medium $(0.05-0.1)$, High $(>0.1)$ \\
\hline Soil texture & Discrete & Sand, Loam, Clay \\
\hline Landuse & Discrete & $\begin{array}{l}\text { Dense range, Moderately dense range, Sparse range, } \\
\text { Cultivated land, Bare rock water urban, Forest }\end{array}$ \\
\hline Interception & Continuous & $\begin{array}{l}\text { Low ( }<10 \mathrm{~mm} / \text { day }) \text {, Medium }(10-20 \mathrm{~mm} / \text { day }) \text {, High }(>20 \\
\mathrm{mm} / \text { day })\end{array}$ \\
\hline Runoff & Continuous & Low, Medium, High \\
\hline Actual evaporation & Continuous & Low ( $<10 \%$ Mean Annual Precipitation), Medium $( \pm 10 \%$ \\
\hline
\end{tabular}


Infiltration Continuous Low, Medium, High

\section{3. Results and discussion}

275 The graph of the base-flow separation from the daily total flow for measured discharges over the 276 period of 2000-2014 at the Karebas Hydrometric Station is shown in Fig.5. By means of a trial 277 and error method, the initial calibration process of the water balance model was carried out 278 manually. The optimized parameters for calibration are presented in Table 2. For these optimal 279 values, the Nash-Sutcliffe efficiency coefficient and the determination coefficient were used to 280 evaluate the model's performance in a direct runoff simulation. The baseline flow and total flow 281 of the studied basin in the calibration and validation periods are presented in Table 3.The value 282 of Nash-Sutcliff coefficient for the flow of the entire basin for calibration and validation period 283 were 0.61 and 0.58 , respectively. According to the table, simulated flow is reliable (based on 284 Gitau and Chaubey, 2010). 


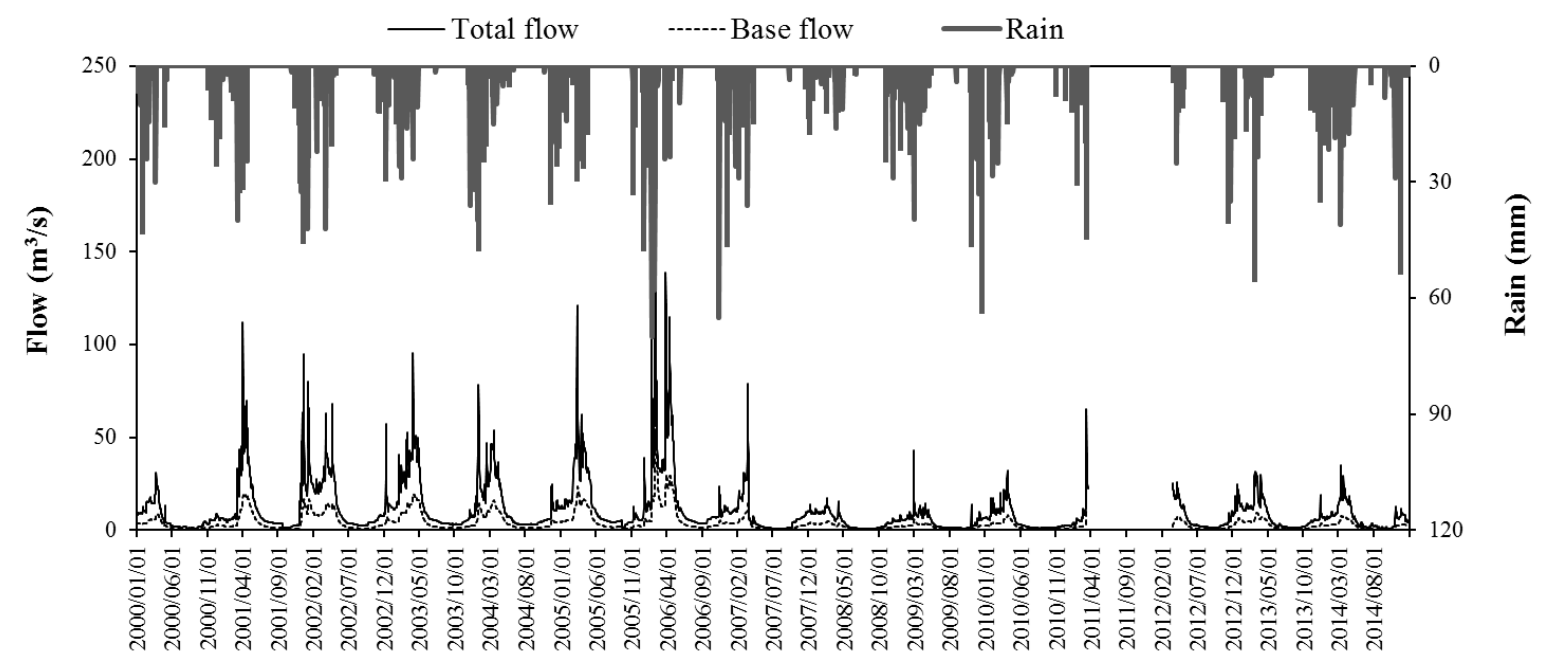

Time (day)

Fig. 5.The separation hydrograph of the base-flow from total flow from studied watershed.

Table 2. The optimal parameters of water balance model at calibration stage.

\begin{tabular}{ccc}
\hline Parameter & Parameter & Optimum value \\
& characteristic & \\
\hline Interception & $\mathrm{a}$ & 2.5 \\
Evapotranspiration & $\alpha$ & 0.8 \\
Surface runoff & LP & 2.8 \\
Snow melting Factor & MF & 0.02 \\
Surface runoff & $\mathrm{X}$ & 0.7 \\
Base-flow & $\beta$ & 0.63 \\
Nutrition Participant & $\varnothing$ & 0.149 \\
\hline
\end{tabular}

Table3.The results of statistical criteria for calibration and validation periods.

\begin{tabular}{cccc}
\hline Period & Parameter & ENS & $\mathbf{R}^{\mathbf{2}}$ \\
\hline \multirow{2}{*}{ Calibration } & Direct runoff & 0.62 & 0.64 \\
& Base-flow & 0.6 & 0.62
\end{tabular}




\begin{tabular}{lccc}
\hline & Total flow & 0.61 & 0.65 \\
\hline \multirow{3}{*}{ Validation } & Direct runoff & 0.51 & 0.52 \\
& Base-flow & 0.67 & 0.7 \\
& Total flow & 0.58 & 0.59 \\
\hline
\end{tabular}

\section{3.1. Surface and sub-surface flow simulation}

294 Fig. 6 shows the observed and simulated hydrograph of the Karebas watershed. Themissing part 295 in the graph is related to unavailability of discharge data of Karebas Hydrometric Station. As the 296 figure also shows, in wet months the simulated flow rate are greater than the observational 297 values. Although there is a difference between observation and simulation flows, in some peak 298 flow in the hydrograph, in some other cases the model has captured the peakwell 299 (simulatedhydrograph in February 2006).On average, the highest simulation errors belong to 300 Marchand April, when the simulated discharge is typically less than the observational values. In 301 these months, a combination of rainfall and the air warming leads to quick snow melt. This 302 means the degree-day snow melt has shown a functional limitation over this period of 303 simulation. The lowest flow simulation error belongs to September, which the model has 304 simulated the flow of the basin with slight differences. In general, the simulated flow of the 305 model has followed the trend of observational flow changes at Karebas watershed outlet. 


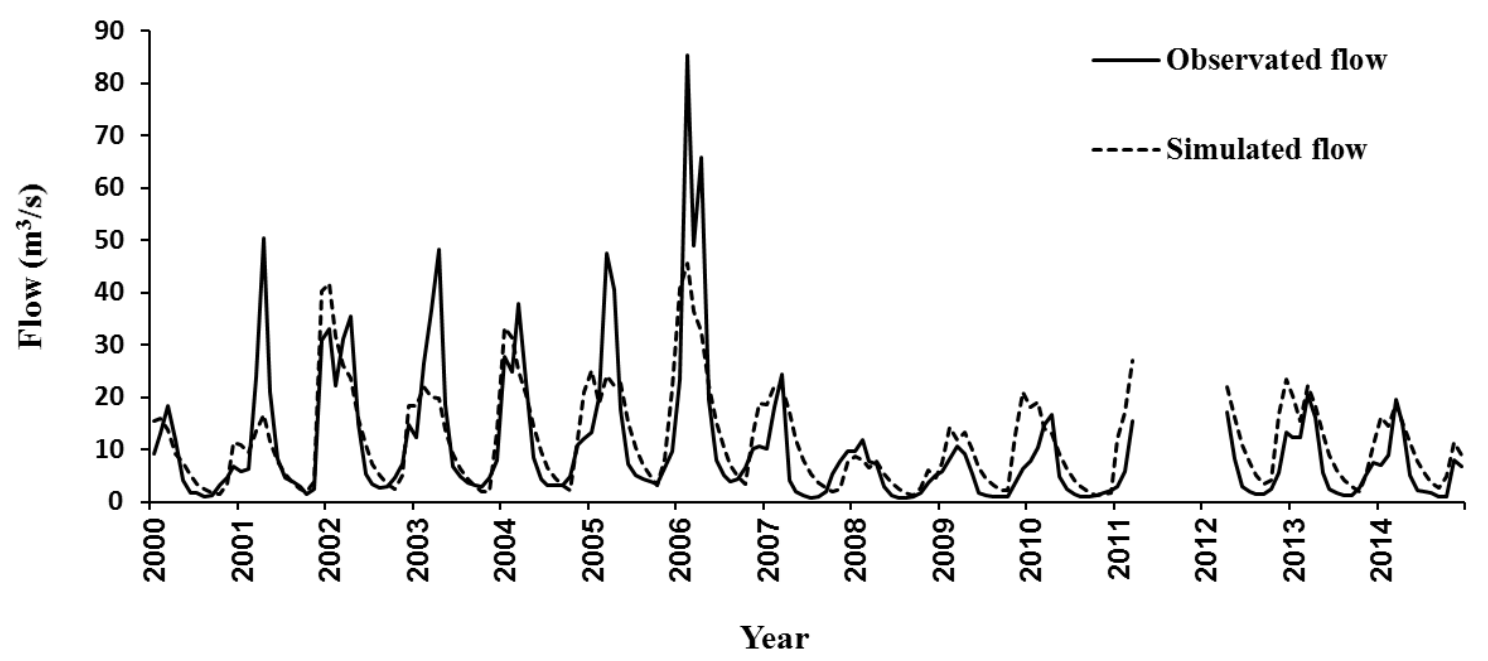

307 Fig. 6.Simulated and observed flow hydrograph in Karebas Hydrometric Station.

\subsection{The effect of fire on the components of water balance}

The results of the percentage changes for fire/non-fire scenarios in runoff, groundwater recharge and evaporation in millimeters were shown in Table 4.According to the results, by applying the

311 fire scenario, the average amount of runoff in the basin increased by $13.5 \%$ and the actual 312 evapotranspiration and groundwater recharge decreased by $4.45 \%$ and $52.2 \%$ respectively. Fig. 7

313 also shows the percentage of changes in the water balance components after applying the fire

314 effects. Under this condition, the amount of actual evaporation and groundwater recharge in all 315 land use classes (poor, moderate, and good rangelands and sparse forest) were decreased while 316 the amount of runoff was increased. The highest percentage of variation can be seen in the 317 amount of actual evaporation. This result is in agreement with the study of Black et al.(2016) 318 that post-fire evapotranspiration was significantly reduced in all three types of land cover, 319 including grasslands, savanna, and croplands. As shown in Fig. 7, the greatest reduction in actual 320 evapotranspiration belongs to poor, moderate, good rangelands and sparse forest. The reason for 321 this sharp change can be related to the type of land cover and its coverage characteristics. In poor 
322 rangelands, it may lose the most of vegetal cover and a major reduction in evaporation and

323 interception may be seen after fire occurrence. In contrast, for forest lands, unless the intensity of

324 the fire is extensive due to stronger land cover, remaining materials and renewed coverage

325 increase after fire occurrence. The type of land utilization also has a great impact. For example,

326 poor and medium rangelands are exposed to severe and moderate grazing respectively, whereas

327 in good rangelands, grazing is usually light. This is why the restoration of land cover may be

328 accelerated in good rangelands while this takes a much longer time in poor rangelands. After the

329 degradation of land cover, due to the formation of an impermeable layer, the amount of

330 infiltrated water into the soil decreases, thus the runoff increases. Letey (2001) and Shakesby and

331 Doerr (2006) reported transmissibility as the responsible cause of reduction of

332 infiltration.Gholami-Gohareh et al. (2012)stated an increscent in fine particles like residual ash

333 may be responsible to filling the pores and reduction in permeability of the burnt soil under the

334 bush cover. Reduction of permeability due to mild and severe fire is reported in some other 335 studies as well (interested readers refer to Robichaud (2000), Martin and Moody 336 (2001),Gonzalez-Pelayo et al. (2010), and Robichaud et al. (2016)). There was also little 337 difference in the percentage of groundwater recharge. Jafarian and Sepehri (2018), stated that the 338 intensity of the fire affects the amount of final infiltration of the soil. Infiltration after the mild 339 and control fire was no different. This may be because of what little remains on the surface of the 340 soil acts like land cover in the treatment without fire. However, in the severe fire, the entire land 341 cover is greatly impacted resulting in more water contributing to runoff instead of infiltration.

343 Table 4.Long-term values and their percentage change for water balance components under 344 fire/none-fire scenarios. 


\begin{tabular}{lccc}
\hline Water balance components & $\begin{array}{c}\text { Evapotranspiration } \\
(\mathrm{mm})\end{array}$ & $\begin{array}{c}\text { Runoff } \\
(\mathrm{mm})\end{array}$ & $\begin{array}{c}\text { Recharge } \\
(\mathrm{mm})\end{array}$ \\
\hline Before fire & 1357.09 & 1202.88 & 4074.61 \\
After fire & 1296.72 & 1365.24 & 3971.89 \\
Percentage of changes & $-4.45 \%$ & $13.5 \%$ & $-2.52 \%$
\end{tabular}

345

346

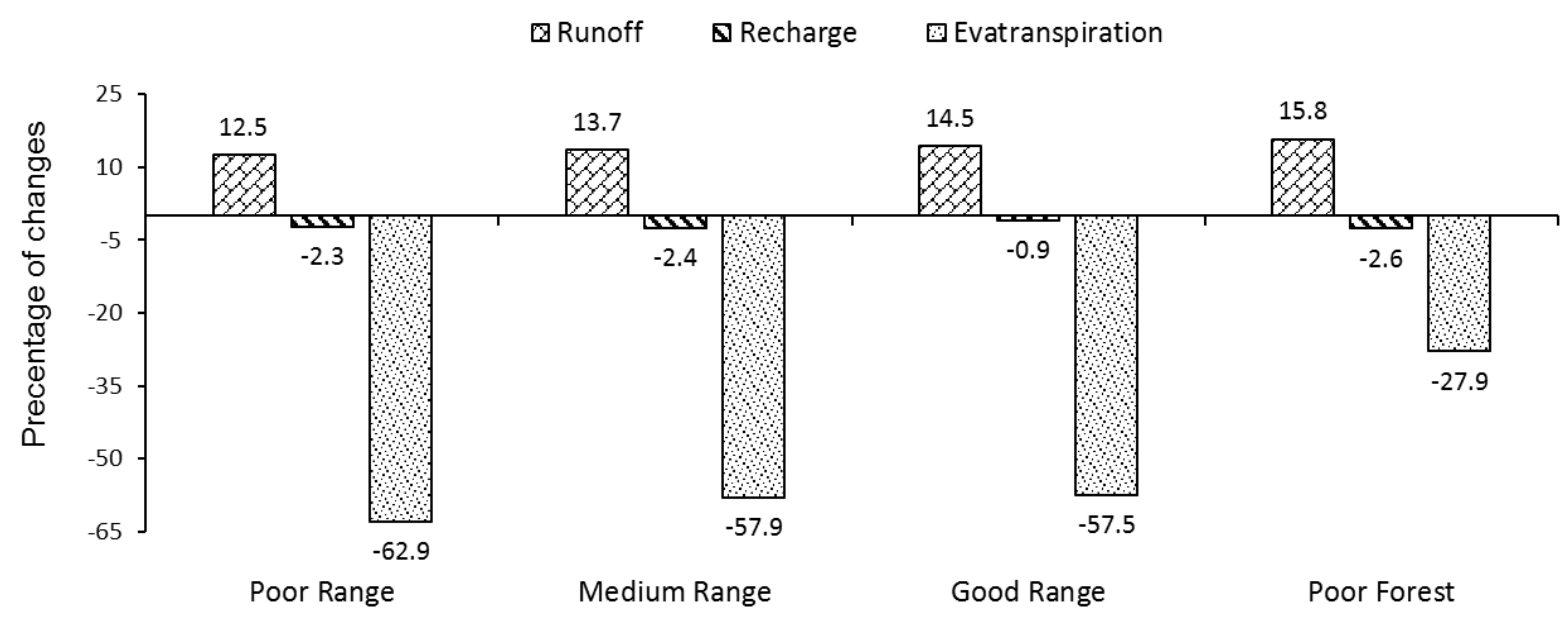

347 Fig.7. The variation of water balance components in different uses after the fire in the study

348 basin.

349

\subsection{The results of $B B N$ modeling}

350 The graphical representation of BNN modeling for the first and second scenarios are shown in

351 Fig. 8 and Fig.9. The bar graph in Fig. 10 shows the probability distribution of each node

352 changing according to its conditional probability. For the first scenario where (no fire) with a

353 high percentage of vegetation and manning coefficient, the soil water reaches to $58.3 \%$ under the

354 wet and very humid states (Fig. 8). For the second scenario where the fire reduces both

355 percentage of vegetation cover and Manning coefficient, soil water dropped to $46.7 \%$ (dry 
condition) (Fig. 9). The reason for this reduction is less flow resistance due to reducing the

357 surface roughness coefficient. This leads to an increased runoff coefficient and a reduced

358 infiltration into the soil. The sensitivity analysis of the Bayesian model showed that runoff acts

359 as the major affecting factor on soil water balance $(50.36 \%)$ followed by land use $(10.49 \%)$, and

360 infiltration (10.12\%).Therefore, after the fire occurrence, vegetation cover decreases and runoff

361 coefficient increases significantly. As seen from the changes in the simulated water balance

362 components under two scenarios by WetSpass-M, the highest percentage of change in water

363 balance components belongs to the surface runoff $13.5 \%$ (Table 4 ).

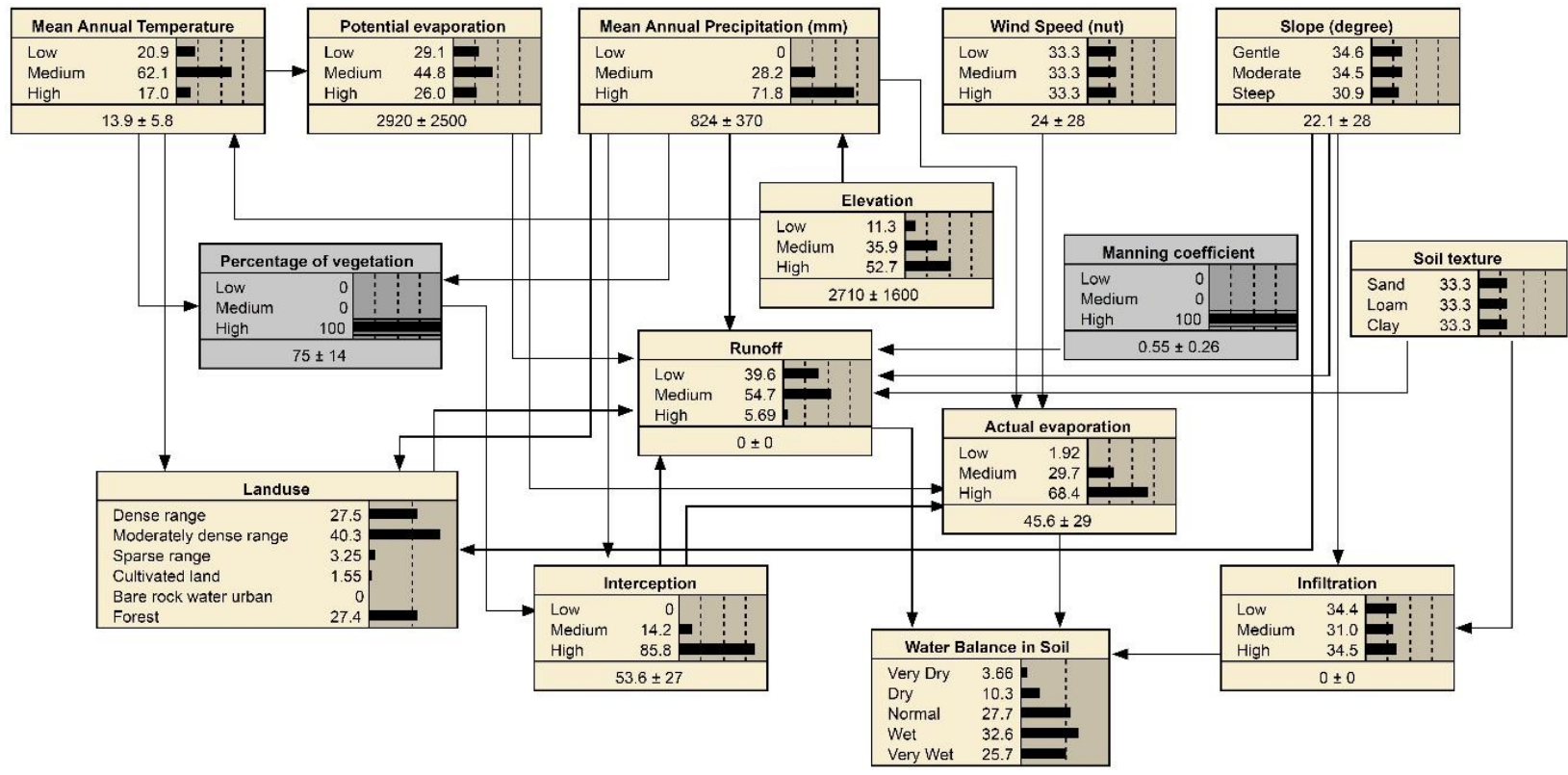

Fig. 8. Soil water balance BBN model for no-fire scenario 


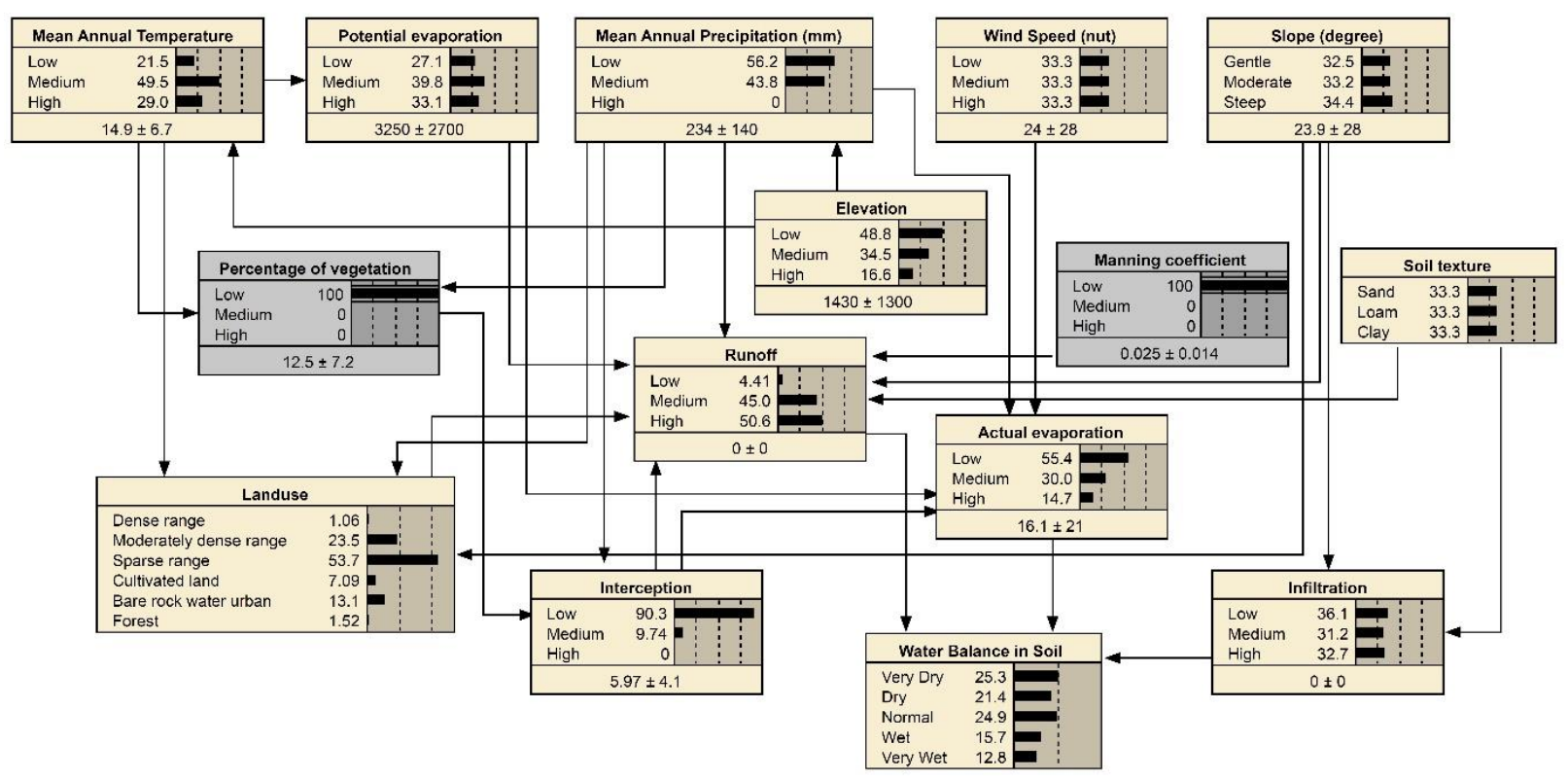

Fig.9. Soil water balance BBN model for the fire scenario

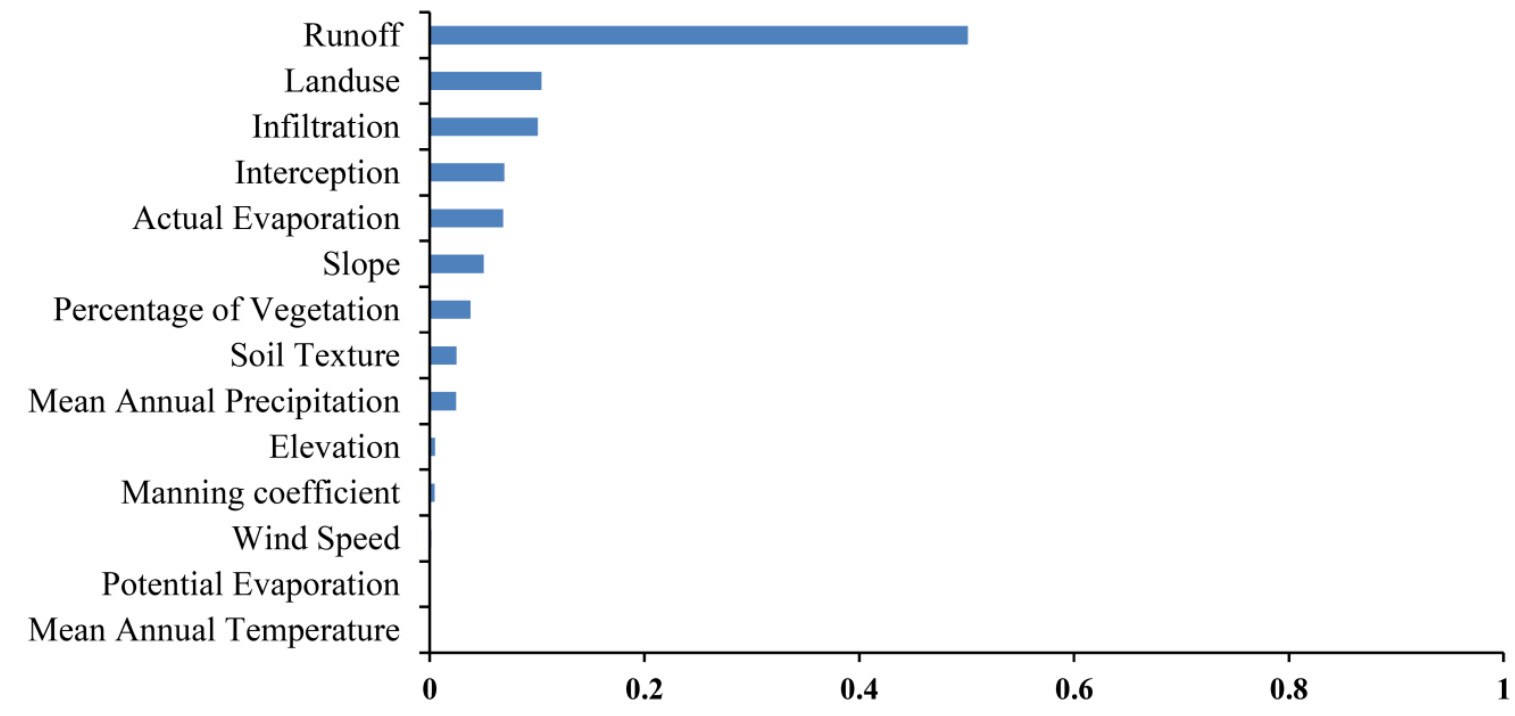

Muatual information 
373 Comparison of the observed and simulated hydrographs by water balance model showed that the

374 model was able to simulate streamflow components of Karebas watershed with satisfactory

375 accuracy. The greatest difference between observed and simulated flow rates is related to high

376 flows occurring in March and April. A possible explanation for this might be because the basin is

377 relatively mountainous and, during cold months, precipitation mostly falls in the form of snow.

378 With increasing temperature during spring, snowmelt could be intensified. It seems that the

379 internal degree-day module of WetSpass-M may not able to capture intensified snowmelt runoff.

380 The results of the analysis of water balance components according to two scenarios showed that 381 the fire has a reduced groundwater recharge(Groundwater recharge, soil moisture and subsurface

382 flow).A similar conclusion also was concluded from Bayesian analysis. The BBN model also 383 produced a significant increase in runoff by reducing vegetation cover and roughness coefficients 384 comparing non-fire scenario with fire scenarios. Analysis of water balance components of 385 different land use classes shows that actual evapotranspiration (interception, transpiration from 386 plants and soil evaporation) has been decreased remarkably in the poor rangeland. The reason for 387 this effect is that the removal of vegetated cover has caused minimal plant transpiration.

388 Seeing that sparse forest class contains less vegetated coverage, it expected to lose less biomass 389 after the occurrence of a fire, unless the intensity of the fire be very extensive. One of the reasons 390 for reducing groundwater recharge and increasing runoff in the basin after the fire occurrence 391 could be the removal of the land cover factor.Land coverhas a direct relationship with infiltration 392 and permeability of the soil,hence it decreases the runoff rate. The results of this study were not 393 able to find a great difference among the percentage of runoff and groundwater recharge 394 variations in different land uses. A possible reason for this might be due to the different intensity 395 of fire in different land uses. 


\section{Funding:}

398 This study was funded by the Research and Technology Deputy of Shahrekord University 399

\section{References}

1. Abdollahi, K., Bashir, I. and Batelaan, O., 2012. WetSpass graphical user interface. Cartography of Higher Swiss Education. Version 31-05-2012. Vrije Universiteit Brussel.

2. Abdollahi, K., 2015. Basin scale water balance modeling for variable hydrological regimes

3. Abdollahi, K., Bashir, I., Verbeiren, B., Harouna, M.R., Van Griensven, A., Huysmans, M. and Batelaan, O., 2017. A distributed monthly water balance model: formulation and application on Black Volta Basin. Environ Earth Sci. 76 (198), 1-18. https://doi.org/10.1007/s12665-017-6512-1.

4. Adab, H., Kanniah, D. and Solaimani, K., 2011. GIS-based probability assessment of fire risk in grassland and forested landscapes of Golestan Province, Iran. In International conference on environmental and computer science IPCBEE. Singapore. 19, 170-175.

5. Al Kuisi, M. and El-Naqa, A., 2013. GIS based spatial groundwater recharge estimation in the Jafr basin, Jordan-application of WetSpass models for arid regions. Rev Mex Cinc Geol. 30(1), 96-109.

6. Arnold, J.G. and Allen, P.M., 1999. Automated methods for estimating baseflow and ground water recharge from streamflow records 1. J Am Water Resour As. 35(2), 411424.https://doi.org/10.1111/j.1752-1688.1999.tb03599.x. 
7. Badia, D. and Marti, C., 2003. Plant ash and heat intensity effects on chemical and physical properties of two contrasting soils. Arid Land Res Manag. 17(1), 23-41. https://doi.org/10.1080/15324980301595.

8. Bahlakeh, K., Abedi, M. and Dianati Tilaki, G., 2017. Competition effects of Onobrychis cornuta changes between exposures and fire (Case Study Golestan Natural Park). Rangeland J. 11(3), 342-352. (In Persian).

9. Bashari, H., Naghipour, A.A., Khajeddin, S.J., Sangoony, H. and Tahmasebi, P., 2016. Risk of fire occurrence in arid and semi-arid ecosystems of Iran: an investigation using Bayesian belief networks. Environ Monit Assess. 188(9), 531. https://doi.org/10.1007/s10661-016-5532-8.

10. Batelaan, O. and De Smedt, F.L.O.R.I.M.O.N.D., 2001. WetSpass: a flexible, GIS based, distributed recharge methodology for regional groundwater modelling. IAHS Publication. 269, 11-18.

11. Benavides-Solorio, J. and MacDonald, L.H., 2001. Post-fire runoff and erosion from simulated rainfall on small plots, Colorado Front Range. Hydrol Process. 15(15), 29312952. https://doi.org/10.1002/hyp.383.

12. Benavides-Solorio, J.D. and MacDonald, L.H., 2005. Measurement and prediction of postfire erosion at the hillslope scale, Colorado Front Range. Int J Wildland Fire. 14(4), 457474. https://doi.org/10.1071/WF05042.

13. Binam. 2014-2018. Agricultural Statistics, ICT Center, Ministry of Agricultural Jihad.

14. Black, F.W., Lee, J., Ellison, L., Gupta, M., Bolten, J.D., Gatebe, C.K., and Ichoku, C.M. 2016. Biomass burning and its relationship with water cycle dynamics of the Chari-Logone catchment of Lake Chad Basin. In AGU Fall Meeting Abstract. 
15. Bond, W.J. and Keeley, J.E., 2005. Fire as a global 'herbivore': the ecology and evolution of flammable ecosystems. Trends Ecol Evol. 20(7), 387-394. https://doi.org/10.1016/j.tree.2005.04.025.

16. DeBano, L.F., 2000. The role of fire and soil heating on water repellency in wildland environments: a review. J Hydrol. 231, 195-206. https://doi.org/10.1016/S00221694(00)00194-3.

17. Eckhardt, K., 2008. A comparison of baseflow indices, which were calculated with seven different baseflow separation methods. J Hydrol. 352(1-2), 168-173. https://doi.org/10.1016/j.jhydrol.2008.01.005.

18. Eskandari, S. and Chuvieco, E., 2015. Fire danger assessment in Iran based on geospatial information. Int J Appl Earth Obs. 42, 57-64. https://doi.org/10.1016/j.jag.2015.05.006.

19. Flerchinger, G.N. and Clark, P.E., 2003. Potential hydrologic response to a prescribed fire on a small mountainous watershed. In First Interagency Conference on Research in the Watersheds-2003 ASAE Annual Meeting (pp. 631-636).

20. Food and Agriculture Organization of the United Nations. Forestry Department (Rome), 2010. Global forest resources assessment 2010: Main report. Food and Agriculture Organization of the United Nations.

21. Gebreyohannes, T., De Smedt, F., Walraevens, K., Gebresilassie, S., Hussien, A., Hagos, M., Amare, K., Deckers, J. and Gebrehiwot, K., 2013. Application of a spatially distributed water balance model for assessing surface water and groundwater resources in the Geba

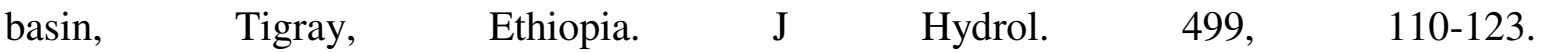
https://doi.org/10.1016/j.jhydrol.2013.06.026. 
22. Gholami-Gohareh, R., Sadeghi, H. And Mirna, Kh., 2012. The effect of mild fires on penetration, runoff and sediment yield of pasture in Kadir area. Iranian Journal of Watershed Management Sciences and Engineering. 5(17), 23 to 32.

23. Gitau, M.W. and Chaubey, I., 2010. Regionalization of SWAT model parameters for use in ungauged watersheds. Water. 2(4), 849-871. https://doi.org/10.3390/w2040849.

24. Gonzalez-Pelayo, O., Andreu, V., Gimeno-Garcia, E., Campo, J. and Rubio, J.L., 2010. Effects of fire and vegetation cover on hydrological characteristics of a Mediterranean shrubland soil. Hydrol Process. 24(11), 1504-1513. https://doi.org/10.1002/hyp.7612.

25. Graf, R. and Przybyłek, J., 2014. Estimation of shallow groundwater recharge using a GISbased distributed water balance model. Quaestiones Geographicae. 33(3), 27-37. https://doi.org/10.2478/quageo-2014-0027.

26. Graf, R. and Jawgiel, K., 2018. The Impact of the Parameterisation of Physiographic Features of Urbanised Catchment Areas on the Spatial Distribution of Components of the Water Balance Using the WetSpass Model. ISPRS Int J Geo-Inf. 7(7), 278. https://doi.org/10.3390/ijgi7070278.

27. Hemmatboland, I., Akbarinia, M. and Shafiei, A.B., 2010. The effect of fire on some soil chemical properties of oak forests in Marivan region. Iran J For Pop Res. 18(2), 205-218.

28. Heydari, J., GHORBANI, D.S., Raiesi, F. and Tahmasebi, P., 2014. Effect of rangeland fire on soil physical properties and water infiltration parameters using principle component analysis. Journal of Water and Soil. 28(5), 964-975. (In Persian).

29. Heydari, M., Salehi, A., Mahdavi, A. and Adibnejad, M., 2012. Effects of different fire severity levels on soil chemical and physical properties in Zagros forests of western Iran. Folia ForestaliaPolonica. 54 (4), 241-250. 
30. Jafarian, Z. and Sepehri, Z.,2018. The Effect of Fire Severity on Soil Permeability Components in Different Seasons (Case Study: Cherat Rangeland Watershed of Mazandaran Province). Watershed Management Research. 9(17), 206-215. (In Persian).

31. Kajewska-Szkudlarek, J., Kubicz, J., Kajewski, I. and Dąbek, P., 2017. Ocena zasobow odnawialnych wod podziemnych Pomorza Zachodniego na podstawie modelu symulacyjnego WetSpass. Przegląd Geologiczny. 65(11/1), 1080-1084.

32. Kavdir, Y., Ekinci, H.U.S.E.Y.I.N., Yuksel, O. and Mermut, A.R., 2005. Soil aggregate stability and 13C CP/MAS-NMR assessment of organic matter in soils influenced by forest wildfires in Canakkale, Turkey. Geoderma. 129(3-4), 219-229. https://doi.org/10.1016/j.geoderma.2005.01.013.

33. Kunze, M.D. and Stednick, J.D., 2006. Streamflow and suspended sediment yield following the 2000 Bobcat fire, Colorado. Hydrol Process: An International Journal. 20(8), 1661-1681. https://doi.org/10.1002/hyp.5954.

34. Leone, V., Lovreglio, R., Martín, M.P., Martínez, J. and Vilar, L., 2009. Human factors of fire occurrence in the Mediterranean. In Earth observation of wildland fires in Mediterranean ecosystems (pp. 149-170). Springer, Berlin, Heidelberg.https://doi.org/10.1007/978-3-642-01754-4_11.

35. Letey, J., 2001. Causes and consequences of fire-induced soil water repellency. Hydrol Process. 15(15), 2867-2875.https://doi.org/10.1002/hyp.378.

36. Madsen, M.D., Petersen, S.L., Fernelius, K.J., Roundy, B.A., Taylor, A.G. and Hopkins, B.G., 2012. Influence of soil water repellency on seedling emergence and plant survival in a burned semi-arid woodland. Arid Land Res Manag. 26(3), 236249.https://doi.org/10.1080/15324982.2012.680655. 
37. Martin, D.A. and Moody, J.A., 2001. Comparison of soil infiltration rates in burned and unburned mountainous watersheds. Hydrol Process. 15(15), 2893-2903. https://doi.org/10.1002/hyp.380.

38. Mataix-Solera, J. and Doerr, S.H., 2004. Hydrophobicity and aggregate stability in calcareous topsoils from fire-affected pine forests in southeastern Spain. Geoderma. 118(12), 77-88.https://doi.org/10.1016/S0016-7061(03)00185-X.

39. Moody, J.A. and Martin, D.A., 2009. Synthesis of sediment yields after wildland fire in different rainfall regimes in the western United States. Int J Wildland Fire. 18(1), 96115.https://doi.org/10.1071/WF07162.

40. Naghipour, A.A., Bashari, H., Khajeddin, S.J., Tahmasebi, P. and Iravani, M., 2016. Effects of smoke, ash and heat shock on seed germination of seven species from Central Zagros rangelands in the semi-arid region of Iran. Afr J Range For Sci. 33(1), 6771.https://doi.org/10.2989/10220119.2015.1119194.

41. Nash, J.E. and Sutcliffe, J.V., 1970. River flow forecasting through conceptual models part I-A discussion of principles. J Hydrol. 10(3), 282-290.https://doi.org/10.1016/00221694(70)90255-6.

42. Pan, Y., Gong, H., ZHou, D., Li, X. and Nakagoshi, N., 2011. Impact of land use change on groundwater recharge in Guishui River Basin, China. Chin Geogr Sci. 21, 734-743. https://doi.org/10.1007/s11769-011-0508-7.

43. Pandian, M., Rajasimman, U.A.B. and Saravanavel, J., 2014. Identification of Groundwater Potential Recharge Zones using WETSPASS Model in Parts of Coimbatore and Tiruppur Districts in Tamil Nadu, India. International Journal of Water Research, Universal Research Publications. 2(1), 27-32. 
44. Papakosta, P. and Straub, D., 2011. Effect of weather conditions, geography and population density on wildfire occurrence: a Bayesian network model. In M. H. Faber, J. Kohler, \& K. Nishijim (Eds.), Applications of statistics and probability in civil engineering. p.93.

45. Paul, M.J., 2006. Impact of land-use patterns on distributed groundwater recharge and discharge. Chin Geograph Sc. 16(3), 229-235. https://doi.org/10.1007/s11769-006-0229-5.

46. Renard, Q., Pélissier, R., Ramesh, B.R. and Kodandapani, N., 2012. Environmental susceptibility model for predicting forest fire occurrence in the Western Ghats of India. Int J Wildland Fire. 21(4), 368-379.https://doi.org/10.1071/WF10109.

47. Robichaud, P.R., 2000. Fire effects on infiltration rates after prescribed fire in Northern Rocky Mountain forests, USA. J Hydrol. 231, 220-229. https://doi.org/10.1016/S00221694(00)00196-7.

48. Robichaud, P.R., Wagenbrenner, J.W., Pierson, F.B., Spaeth, K.E., Ashmun, L.E. and Moffet, C.A., 2016. Infiltration and interrill erosion rates after a wildfire in western Montana, USA. Catena. 142, 77-88. https://doi.org/10.1016/j.catena.2016.01.027.

49. Shakesby, R.A. and Doerr, S.H., 2006. Wildfire as a hydrological and geomorphological agent. Earth-Sci Rev. 74(3-4), 269-307. https://doi.org/10.1016/j.earscirev.2005.10.006.

50. Shakesby, R.A., 2011. Post-wildfire soil erosion in the Mediterranean: review and future $\begin{array}{llll}\text { research } & \text { directions. }\end{array}$ https://doi.org/10.1016/j.earscirev.2011.01.001.

51. Shrestha, S., Bach, T.V. and Pandey, V.P., 2016. Climate change impacts on groundwater resources in Mekong Delta under representative concentration pathways (RCPs) scenarios. Environ Sci Policy. 61, 1-13.https://doi.org/10.1016/j.envsci.2016.03.010. 
52. Soleimani-Motlagh, M., 2017. Evaluation of groundwater balance with emphasis on the fractionation of drought and over-exploitation of aquifer (Case study: Dashte al-Shater). Ph.D. in Watershed Management Science and Engineering. Faculty of Natural Resources and Earth Sciences. University of Kashan. Iran

53. Stoof, C.R., Ferreira, A.J., Mol, W., Van den Berg, J., De Kort, A., Drooger, S., Slingerland, E.C., Mansholt, A.U., Ferreira, C.S. and Ritsema, C.J., 2015. Soil surface changes increase runoff and erosion risk after a low-moderate severity fire. Geoderma. 239, 58-67.https://doi.org/10.1016/j.geoderma.2014.09.020.

54. Thomaz, E.L., Antoneli, V. and Doerr, S.H., 2014. Effects of fire on the physicochemical properties of soil in a slash-and-burn agriculture. Catena. 122, 209-215. https://doi.org/10.1016/j.catena.2014.06.016.

55. Wang, Z.M., Batelaan, O. and De Smedt, F., 1996. A distributed model for water and energy transfer between soil, plants and atmosphere (WetSpa). Phys Chem Earth.21(3), 189-193. https://doi.org/10.1016/S0079-1946(97)85583-8.

56. Wang, Y., Liao, W., Ding, Y., Wang, X., Jiang, Y., Song, X. and Lei, X., 2015. Water resource spatiotemporal pattern evaluation of the upstream Yangtze River corresponding to climate changes. Quatern Int. 380, 187-196.https://doi.org/10.1016/j.quaint.2015.02.023.

57. Willems, P., 2009. A time series tool to support the multi-criteria performance evaluation of rainfall-runoff models. Environ Modell Softw.24(3), 311-321. https://doi.org/10.1016/j.envsoft.2008.09.005.

58. Woldeamlak, S.T., Batelaan, O. and De Smedt, F., 2007. Effects of climate change on the groundwater system in the Grote-Nete catchment, Belgium. Hydrogeol J. 15(5), 891901.https://doi.org/10.1007/s10040-006-0145-x. 
59. Yin, H., Kong, F. and Li, X.Z., 2005. GIS-Based forest fire risk zone mapping in Daxing'an Mountains. Ying Yong Sheng Tai Xue Bao. The journal of applied ecology. 16(5), 833.

60. Zarei, M., Ghazavi, R., Vali, A. and Abdollahi, K., 2016. Estimating groundwater recharge, evapotranspiration and surface runoff using land-use data: a case study in northeast Iran. Biol Forum Int J. 8(2), 196-202.

61. Zhang, Y., Liu, S., Cheng, F. and Shen, Z., 2018. WetSpass-based study of the effects of urbanization on the water balance components at regional and quadrat scales in Beijing, China. Water. 10(1), p.5.https://doi.org/10.3390/w10010005. 


\section{Supplementary Files}

This is a list of supplementary files associated with this preprint. Click to download.

- Graphicalabstract.jpg 